DOI:

UDC 621.9.06-52

A. Shumeyko, doctor of Technical Sciences, professor

V. Korotkov, candidate of Technical Sciences, docent

Dnipro State Technical University, Kamianske

\title{
CREATION MODEL FOR THE CNC MACHINE OF TECHNOLOGICAL SYSTEM PLIABILITY PLIABILITG FOR THE CNC MACHINE
}

The article consider using splines to develop a mathematical model of details shaping surfaces in the cutting process on CNC machines. As a result of workload simulations and obtaining data about technological system pliability, expected processing errors are determined, which can be considered at preparation stage of the control program.

Keywords: Mathematical model; polar splines; system of equations; surface modeling.

В статті розглянутий варіант використання сплайнів для побудови математичної моделі формоутворення поверхонь деталей при обробиі різанням на верстатах з ЧПК. За результатами імітачії робочих навантажень $і$ отримання даних про податливість технологічної системи визначаються очікувані похибки обробки, які можуть бути ураховані на стадії підготовки керуючої програми.

Ключові слова: математична модель; полярні сплайни; система рівнянь; моделювання поверхні.

\section{Problem's Formulation}

A characteristic feature of $\mathrm{CNC}$ machines is the performing of all the main and auxiliary movements of the working parts according to pre-prepared program on the set distance. If such movements are carried out by the form-building tool, the corresponding sizes on a detail surface turn out. Many factors prevent accurate shaping, even when accurately recording movements in the control program. For example, the elastic and thermal deformations of the CNC machine technological system elements, actually present during metalworking, and each machine has its own "individual" characteristics. As a rule, in order to establish the laws governing the formation of possible size deviations during processing, it is necessary to carry out many tests of each $\mathrm{CNC}$ machine, which is very difficult in the production environment.

In this regard, there is a need to create a reliable model of the behavior of the machine in a real technological process to predict the accuracy and quality of processing.

To create a mathematical model, for example, a metalworking process on $\mathrm{CNC}$ machines with a high degree of reliability, it is necessary to conduct a variety of tests simulating real processes, which can be carried out using special devices [1,2]. For contour milling, the scheme of simulation actions on a forming tool, for example, an end mill, is shown in figure 1 , where radiuses $r_{1}, r_{2}, \ldots-$ the deviation values of the center of the tool under the influence of simulation efforts, enclosed at an angle

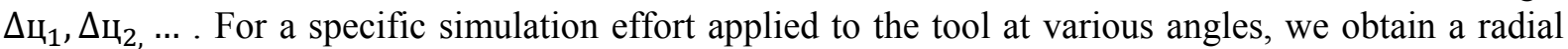
diagram.

The objective of the research is to establish, with the help of a mathematical model of the flexibility of the $\mathrm{CNC}$ machine, the probable deviations of the tool from the programmed value in the entire range of workloads and the directions of their action. And, creation of the model is carried out according to limited experimental research for a particular machine. This approach significantly reduces the complexity of testing and allows you to analyze the processes of formation of processing errors.

The results obtained are based on a completely constructive hypothesis that, within the framework of the machine's operating modes, the processing accuracy changes continuously.

Let's pass to formalization of a task. 
Let the values received at some duty of the machine be described by a curve $=r(ц)$, set by points of the measurements received as a result of carrying out an experiment $\left(\iota_{i}, r_{i}\right)(i=0,1, \ldots, n)$, at that

and

$$
0=\bigsqcup_{0}<ц_{1}<\bigsqcup_{2} \ldots<ц_{n}<2 \mathrm{p}
$$

and

$$
r_{i} \geq 0 \quad(i=0,1, \ldots, n), r_{0}=r_{n}
$$

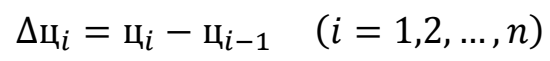

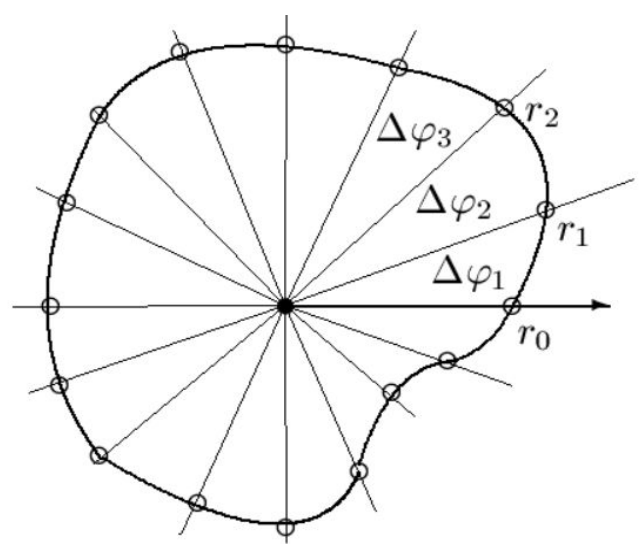

Fig. 1. Diagram of the formation of deviations of the position of the tool under the action of simulation efforts at various angles

Further we will consider a case when

and we assume that for all

$$
\bigsqcup_{i}=\frac{\mathrm{p} i}{n} \quad(i=0,1, \ldots m 2 n)
$$

$$
\begin{gathered}
i \in Z \\
r_{i}=r_{i}+2 n .
\end{gathered}
$$

First, we introduce some notation needed later on.

\section{Analysis of recent research and publications \\ Splines on a uniform grid}

Splines are called piecewise polynomial functions with a homogeneous structure $[3,4,5]$. The most common and historically earliest example of a spline is a broken line. Splines have a number of great features that have made them successful in a variety of applications. So, in comparison with the classical apparatus of approximation of functions, splines have better approximative properties.

Spline of minimum defect of an order $r$ by given partition

$$
\Delta h=\{i h\} \infty i=-\infty \Delta h=\{i h\}
$$

called $r-1$ times continuously differentiable function $\operatorname{sr}(t)$, which at each interval $(i h,(i+1) h)$ $(i=0, \pm 1, \pm 2, \ldots)$ is a polynomial of degree not higher $r r$.

Note that on the set of splines of order $r(\geq 0)$ there is a spline identically equal to zero and a spline identically equal to one.

From here and from the fact that the work of a polynomial of degree of $r$ on number $\sigma$ is a polynomial of the same degree if $\sigma \neq 0$ and the identity zero for $\sigma=0$, as well as the fact that the sum of polynomials of degree $n<m<r \quad$ и $m<r m<r$ is a polynomial of degree no higher than $r$, we see that the set of all splines of degree $r$ over the partition $\Delta \mathrm{h}$ is a linear space.

So if $\operatorname{Sr}(\Delta h)$ the set of all splines of the minimal defect by partition $\Delta h$, and

$$
\mathrm{y}_{r, i} \in S_{r}(\Delta h) i=0, \pm 1, \pm 2, \ldots,
$$

then a linear combination of functions $\mathrm{y}_{r, i}$ will also lie in the set $S_{r}(\Delta h)$, i.e.

$$
\sum i C_{i} i \mathrm{y}_{r, i} \in S_{r}(\Delta h) \text {. }
$$




\section{B-splines}

B-spline represents a spline with the minimum carrier for the fixed degree of a spline and an order of smoothness. The value of B-splines consists that any spline of the given degree and smoothness can be written down in the form of the linear combination of the corresponding B-splines. That is, the B-spline represents "brick" by means of which it is possible to construct a spline with the given properties $[3,4,5]$. Parabolic B-spline is as follows

$$
B_{2, h}(t)=\left\{\begin{array}{c}
0,125\left(3-\frac{2 t}{h}\right)^{2}\left(t \in\left[\frac{h}{2}, \frac{3 h}{2}\right]\right) \\
0,75-0,25\left(\frac{2 t}{h}\right)^{2}\left(t \in\left[-\frac{h}{2}, \frac{h}{2}\right]\right) \\
0,125\left(3+\frac{2 t}{h}\right)^{2}\left(t \in\left[-\frac{3 h}{2},-\frac{h}{2}\right]\right) \\
0(|t| \geq 3 h / 2)
\end{array}\right.
$$

and function graph $B_{2, h}(t)$ has the form

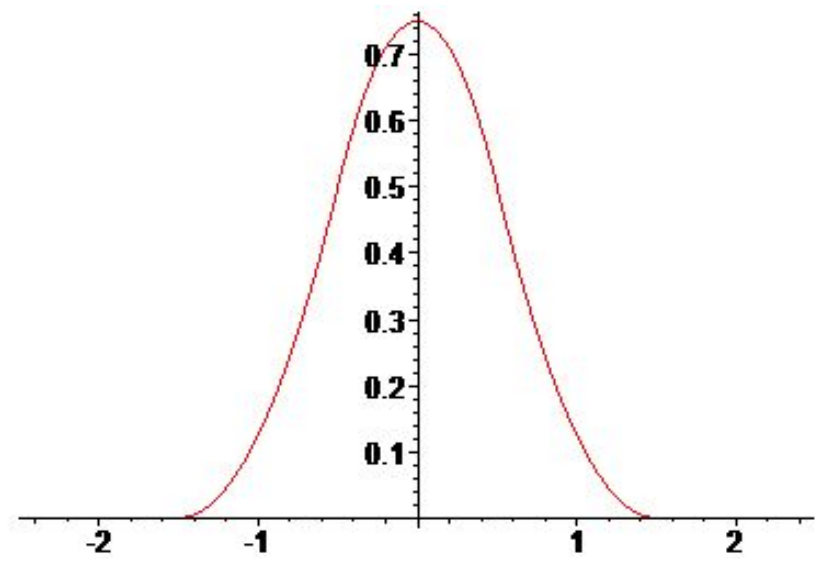

Fig. 2. View of the second-order B-spline

and, accordingly, the parabolic spline of the minimal defect in the partition $\Delta_{h}$ can be written as

$$
S_{2, h}(t)=\sum_{-\infty}^{\infty} c_{i} B_{2, h}(t-(2 i-1) h / 2) \text {. }
$$

It is clear, that for any numbers 脢 $i$ narrowing splines (2) per segment $[0, T]$ (where $T=n h$ ) there is a spline, in addition, for any particular $t \in\left(i h,\left(i_{-} 1\right) / h\right)$ representation (2) uses only three terms. This allows you to write splines (2) as

And for $t \in(i h,(i+1) / h)$

$$
S_{2, h}(t)=\sum_{-i=-1 \infty}^{n+1} c_{i} B_{2, h}(t-(2 i-1) h / 2) .
$$

$$
S_{2, h}(t)=\frac{c_{i+1}+6 c_{i}+c_{i-1}}{8}+\frac{c_{i+1}-c_{i-1}}{2 h}(i-i h)+\frac{c_{i+1}-2 c_{i}+c_{i-1}}{2 h^{2}}(i-i h)^{2} .
$$

Let's consider the splines further called - the polar splines offered in work [5]

$$
\mathrm{c}_{2}(r, ц)=\sum_{i=1}^{2 n}\left(r_{i}-\frac{1}{8} \Delta^{2} r_{i}\right) B_{2, \mathrm{p} / n}\left(ц-ц_{i}\right) .
$$

As already noted, for each value of $ц$, only three terms in (5) are nonzero. More precisely, if

$$
\begin{gathered}
\text { ц } \in[(i-0,5) \mathrm{p} / n,(i+0,5) \mathrm{p} / n], \text { то } \\
\mathrm{c}_{2}(r, \text { ц })=\left(r_{i-1}-\frac{1}{8} \Delta^{2} r_{i_{-} 1}\right) B_{2, \mathrm{p} / n}\left(ц-ц_{i-1}\right)+\left(r_{i}-\frac{1}{8} \Delta^{2} r_{i}\right) B_{2, \mathrm{p} / n}\left(ц-ц_{i}\right)+ \\
+\left(r_{i+1}-\frac{1}{8} \Delta^{2} r_{i+1}\right) B_{2, \mathrm{p} / n}\left(ц-ц_{i+1}\right) .
\end{gathered}
$$

Besides, in work [5], it is shown that for all whole i equalities are carried out

$$
\mathrm{c}_{2}\left(r, Ц_{i}\right)=r_{i}-\frac{1}{64} \Delta^{4} r_{i} .
$$




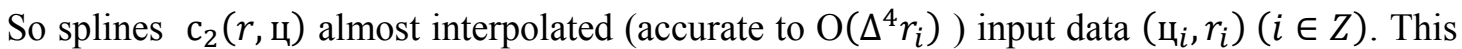
causes many spline properties $\mathrm{c}_{2}(r, ц)$. For example, if $r(ц)$ - three times continuously differentiable $2 p$ - periodic function, then

Besides,

$$
\left\|r-\mathrm{c}_{2}(r)\right\|_{c} \leq \frac{7}{96}\left(\frac{\mathrm{p}}{n}\right)^{3}\left\|r^{(3)}\right\|_{c}
$$

где $\|f\|_{c}=\max _{t}|f(t)|$.

$$
\left\|r^{\prime}-\mathrm{c}_{2}^{\prime}(r)\right\|_{c} \leq \frac{1}{12}\left(\frac{\mathrm{p}}{n}\right)^{3}\left\|r^{(3)}\right\|_{c}
$$

Such results are called a priori or guaranteed accurate estimates for the recovery of smooth curves. They show that splines restore with high accuracy not only the smooth curves themselves, but also their derivatives. From this it is easy to derive asymptotic estimates of the errors in the reconstruction of smooth curves by polar splines.

Let the $r(ц)$ there is three times a periodic function, continuously differentiable on all axis $2 p$. Then for ц $\in\left[\frac{(i-0,5) \mathrm{p}}{n},(i+0,5) \mathrm{p} / n\right]$ при $n \rightarrow \infty$ uniformly across ц and on $i$ ratios are carried out

where $r=\left(ц-ц_{i}\right) /(\mathrm{p} / n)$.

$$
\begin{aligned}
& r(\text { ц })-\mathrm{c}_{2}(r, \text { ц })=\frac{1}{24}\left(\frac{\mathrm{p}}{n}\right)^{3}\left(1-\phi^{2}\right) \phi r^{(3)}(t)+0\left(n^{-4}\right), \\
& r^{\prime}(\text { ц })-\mathrm{c}_{2}^{\prime}(r, \text { ц })=\frac{1}{24}\left(\frac{\mathrm{p}}{n}\right)^{2}\left(1-3 \phi^{2}\right) r^{(3)}(t)+0\left(n^{-3}\right),
\end{aligned}
$$

Thus, using the obtained polar almost interpolation spline, it is possible to within $O\left(n^{-3}\right)$ get any intermediate value of the machine operating mode.

Our further discussion is devoted to the study of those values for which there are no experimental data.

The idea of the proposed design is as follows. We have a data set (radial diagrams) for each experiment. For each set, we construct, using the proposed method, a polar spline. A lot of polar splines are "frames", on which we pull the surface, which, in fact, represents all the possible modes of the $\mathrm{CNC}$ machine, lying in the framework of the experiments. To construct this surface, we will use the tensor product of second-order splines - biquadratic splines.

\section{Tensor product of spaces}

Let $U$ - linear space of functions defined on some set $X$ with values in the domain of real numbers and $V$ - linear space of functions defined on some set $Y$ with values in the space $\mathbb{R}$. $\mathbb{P}^{p}$ For any functions $u \in U$ и $v \in V$ ratio

$$
w(x, y)=u(x) v(y)
$$

For all $(o, y) \in X \Psi Y$ defines a function on a plane $X \Psi Y$, which is called the tensor product of functions $u$ and $v$ and is indicated $u \otimes v$.

The set of all finite linear combinations of functions on the plane $X \Psi Y$ shape $u \otimes v$ called tensor product $U$ and $\bullet$ and is designated $\otimes V$. In this way

$$
U \otimes V=\left\{\sum_{i=1}^{n} c_{i}\left(u_{i} \otimes v_{i}\right): c_{i} \in R, u_{i} \in U, v \in V, i=1, \ldots, n\right\}
$$

and $U \otimes V$ is a linear space defined on a plane $X \times Y$.

Let $U=P_{N}$ - space of algebraic polynomials of order $\mathrm{N}$ defined on the axis of real numbers $X=R$ и $U=P_{M}$ - space of algebraic polynomials of order $M$ on $=R$. Then $U \otimes V$ this is the linear space $P_{N, M}$, whose elements are polynomials of two variables, of degree not higher than $N$ in the first variable and not higher than $M$ in the second, whose domain is the plane $X Y Y=R^{2}$.

\section{Presenting main material}

\section{Main result}

Consider the surface description by the tensor product of B-splines defined on a square lattice $i h=(i h, j h)$, where $i \in Z^{2}$. 
The biquadratic spline of the minimal defect s with nodes at points $(i h, j h)$ is called interpolation for functions $f$ with bounded values $f_{i+\frac{1}{2}, j+1 / 2}$ in points $((i+1 / 2) h,(j+1 / 2) h)$, if

$$
f_{i+\frac{1}{2}, j+\frac{1}{2}}-s_{i+\frac{1}{2}, j+\frac{1}{2}}=0 .
$$

Surface $S_{r, s}(\boldsymbol{u})$, described by the tensor product of B-splines has the form

where $\boldsymbol{u}=(u, v) \in R^{2}$ and

$$
\boldsymbol{S}_{r, s}(\boldsymbol{P}, \boldsymbol{u})=\sum_{i \in Z^{2}} \boldsymbol{P}_{i} N_{r, s}(\boldsymbol{u}-\boldsymbol{i} / h),
$$

$$
N_{r, s}(\boldsymbol{u}-i h) \equiv B_{r}(u-i h) B_{s}(v-j h)
$$

normalized tensor product of B-splines of order rs with a lattice with nodes

$$
i=(i, j) \text {. }
$$

Consider biquadratic splines $\boldsymbol{S}_{2.2}(\boldsymbol{P}, \boldsymbol{u})$. Function graph $N_{2.2}(\boldsymbol{u})$ looks as follows

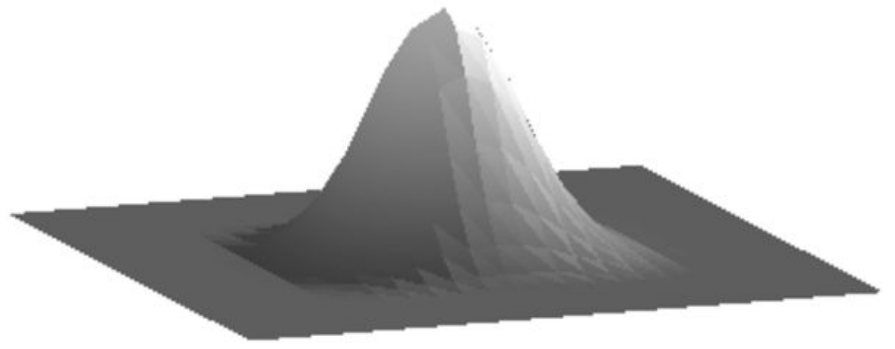

Fig. 3. View of the biquadratic spline $S_{2.2}(P, u)$

Using the type of parabolic B-spline, for $\boldsymbol{u} \in[i h, j h] \mathrm{\Psi}[(i+1) h,(j+1) h]$ get

$$
\begin{gathered}
\boldsymbol{S}_{2,2}(\boldsymbol{P}, \boldsymbol{u})=\sum_{i \in Z^{2}} \boldsymbol{P}_{\boldsymbol{i}} N_{2,2}(u-\boldsymbol{i} h)=\boldsymbol{P}_{i, j} \frac{1+2 \frac{u-i h}{h}-2\left(\frac{u-i h}{h}\right)^{2}}{2} \cdot \frac{1+2 \frac{v-j h}{h}-2\left(\frac{v-j h}{h}\right)^{2}}{2}+ \\
+\boldsymbol{P}_{i-1, j} \frac{\left(1-\frac{u-i h}{h}\right)^{2}}{2} \cdot \frac{1+2 \frac{v-j h}{h}-2\left(\frac{v-j h}{h}\right)^{2}}{2}+\boldsymbol{P}_{i+1, j} \frac{\left(\frac{u-i h}{h}\right)^{2}}{2} \cdot \frac{1+2 \frac{v-j h}{h}-2\left(\frac{v-j h}{h}\right)^{2}}{2} \\
+\boldsymbol{P}_{i, j-1} \frac{1+2 \frac{u-i h}{h}-2\left(\frac{u-i h}{h}\right)^{2}}{2} \cdot \frac{\left(1-\frac{v-j h}{h}\right)^{2}}{2}+ \\
+\boldsymbol{P}_{i-1, j-1} \frac{\left(1-\frac{u-i h}{h}\right)^{2}}{2} \cdot \frac{\left(1-\frac{v-j h}{h}\right)^{2}}{2}+\boldsymbol{P}_{i+1, j-1} \frac{\left(\frac{u-i h}{h}\right)^{2}}{2} \cdot \frac{\left(1-\frac{v-j h}{h}\right)^{2}}{2}+ \\
+\boldsymbol{P}_{i, j+1} \frac{1+2 \frac{u-@ h}{h}-2\left(\frac{u-i h}{h}\right)^{2}}{2} \cdot \frac{\left(\frac{v-j h}{h}\right)^{2}}{2}+\boldsymbol{P}_{i-1, j+1} \frac{\left(1-\frac{u-i h}{h}\right)^{2}}{2} \cdot \frac{\left(\frac{v-j h}{h}\right)^{2}}{2}+\boldsymbol{P}_{i+1, j+1} \frac{\left(\frac{u-i h}{h}\right)^{2}}{2} \cdot \frac{\left(\frac{v-j h}{h}\right)^{2}}{2} .
\end{gathered}
$$

In matrix form, it will have the following form:

$$
\boldsymbol{S}_{2,2}(\boldsymbol{P}, \boldsymbol{u})=\left[\begin{array}{lll}
1 & \frac{u-i h}{h} & \left(\frac{u-i h}{h}\right)^{2}
\end{array}\right] M_{2,2} P_{2,2} M_{2,2}^{T}\left[\begin{array}{c}
1 \\
\frac{v-j h}{h} \\
\left(\frac{v-j h}{h}\right)^{2}
\end{array}\right],
$$

where $M_{2,2}$ - matrix size $3 \times 3$

and

$$
M_{2,2}=\frac{1}{2}\left[\begin{array}{ccc}
1 & 1 & 0 \\
-2 & 2 & 0 \\
1 & -2 & 1
\end{array}\right]
$$

$$
P_{2,2}=\left[\begin{array}{ccc}
\boldsymbol{P}_{i-1, j-1} & \boldsymbol{P}_{i, j-1} & \boldsymbol{P}_{i+1, j-1} \\
\boldsymbol{P}_{i-1, j} & \boldsymbol{P}_{i, j} & \boldsymbol{P}_{i+1, j} \\
\boldsymbol{P}_{i-1, j+1} & \boldsymbol{P}_{i, j+1} & \boldsymbol{P}_{i+1, j+1}
\end{array}\right] \text {. }
$$


From here we immediately get the values at the point $\left(\left(i+\frac{1}{2}\right) h,\left(j+\frac{1}{2}\right) h\right)$ :

$$
\begin{gathered}
\boldsymbol{S}_{2,2}(\boldsymbol{P}, \boldsymbol{i} h)=\frac{9}{16} \boldsymbol{P}_{i, j}+\frac{3}{32}\left(\boldsymbol{P}_{i, j+1}+\boldsymbol{P}_{i, j-1}+\boldsymbol{P}_{i+1, j}+\boldsymbol{P}_{i-1, j}\right)+\frac{1}{64}\left(\boldsymbol{P}_{i-1, j+1}+\boldsymbol{P}_{i-1, j-1}+\boldsymbol{P}_{i+1, j+1}+\right. \\
\left.\boldsymbol{P}_{i+1, j-1}\right)=\boldsymbol{P}_{i, j}-\frac{1}{64} \Delta \boldsymbol{P}_{i, j},
\end{gathered}
$$

where

$$
\Delta \boldsymbol{P}_{i, j}=28 \boldsymbol{P}_{i, j}-6\left(\boldsymbol{P}_{i, j+1}+\boldsymbol{P}_{i, j}+\boldsymbol{P}_{i+1, j}+\boldsymbol{P}_{i-1, j}\right)-\left(\boldsymbol{P}_{i+1, j+1}+\boldsymbol{P}_{i+1, j-1}+\boldsymbol{P}_{i-1, j-1}+\boldsymbol{P}_{i-1, j+1}\right) .
$$

Let the surface $\boldsymbol{f}$ be given by the points

$$
f_{i+1 / 2}=f\left(\left(i+\frac{1}{2}\right) h,\left(j+\frac{1}{2}\right) h\right), \quad(i, j=0, \pm 1, \pm 2, \ldots)
$$

and

$$
\begin{gathered}
\boldsymbol{P}_{i}^{1}=\boldsymbol{P}_{i}^{1}(\boldsymbol{f})-f_{i+\frac{1}{2}}+\frac{1}{64} \Delta f_{i+\frac{1}{2},}=\frac{23}{16} f_{i+\frac{1}{2}, j+\frac{1}{2}}-\frac{3}{32}\left(f_{i+\frac{1}{2}, j+\frac{3}{2}}+f_{i+\frac{1}{2}, j-\frac{1}{2}}+f_{i+\frac{3}{2}, j+\frac{1}{2}}+f_{i-\frac{1}{2}, j+\frac{1}{2}}\right)- \\
-\frac{1}{64}\left(f_{i-\frac{1}{2}, j+3 / 2}+f_{i-\frac{1}{2}, j-1 / 2}+f_{i+\frac{3}{2}, j-1 / 2}+f_{i+\frac{3}{2}, j+3 / 2}\right)
\end{gathered}
$$

The corresponding spline is denoted by

$$
S_{2,2}^{1}(\boldsymbol{P}, \boldsymbol{u})=\sum_{i \in Z^{2}} \boldsymbol{P}_{i}^{1} N_{2,2}(\boldsymbol{u}-i h) .
$$

when

$$
S_{2,2}^{1}\left(f,\left(i+\frac{1}{2}\right) h\right)-f_{i+\frac{1}{2}}+\frac{1}{4096} \Delta^{2} f_{i+1 / 2} .
$$

If the function $f(\boldsymbol{u})$ has all continuous derivatives up to fourth order inclusive, then there exists a point $\boldsymbol{u}_{0} \in[i h, j h] \mathrm{Y}[(i+1) h,(j+1) h]$ such that

$$
S_{2,2}^{1}\left(\boldsymbol{f},\left(\boldsymbol{i}+\frac{1}{2}\right) h\right)=f_{i+1 / 2}+\frac{3}{8} h^{4}\left(\left.\frac{\partial^{4} f}{\partial u^{4}}\right|_{u_{0}}+\left.2 \frac{\partial^{4} f}{\partial u^{2} \partial v^{2}}\right|_{u_{0}}+\left.\frac{\partial^{4} f}{\partial v^{4}}\right|_{u_{0}}\right) .
$$

In work [6] it is shown that if $f(x, y) \in C^{6}\left(R^{2}\right)$, what

$$
f_{i, j}-S_{i, j}=\frac{h^{4}}{128}\left(\left.\frac{\partial^{4} f}{\partial x^{4}}\right|_{(i h, j h)}+\left.\frac{\partial^{4} f}{\partial y^{4}}\right|_{(i h, j h)}\right)+O\left(h^{6}\right), h \rightarrow 0 .
$$

That is, the spline $S_{2,2}^{1}$ asymptotically coincides with the interpolation biquadratic spline $\mathrm{S}$.

We examined biquadratic splines defined on the entire plane $R^{2}$. Let $\Omega=[0, H h] \cup[0, W h]$ rectangle with square step grid $h$.

Then, to obtain an interpolation biquadratic spline, it is necessary to solve a system of $H \Psi W$ linear equations. From relations (9) и (10) it is clear, that splines $\boldsymbol{S}_{2,2}^{1}$ asymptotically coincide with interpolation and without significant loss of accuracy, instead of interpolation splines, we can use splines $S_{2,2}^{1}$.

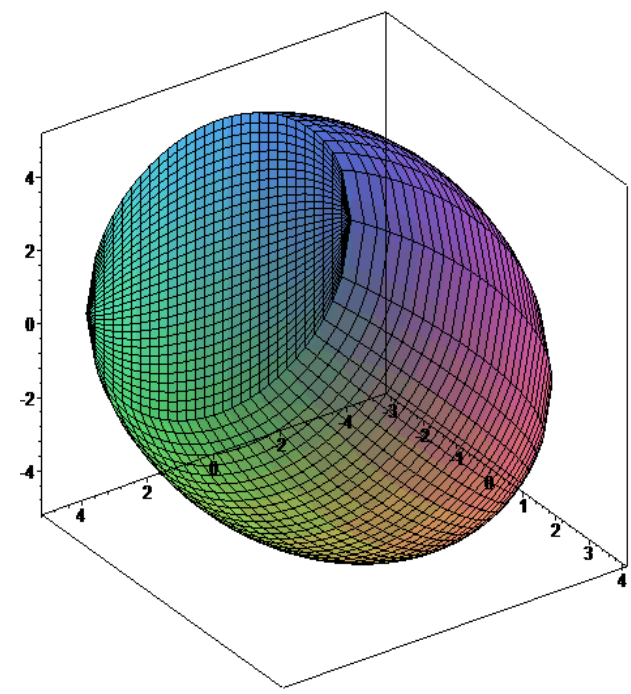

Fig. 4. Spline-surface, simulating these $\mathrm{CNC}$ machine operating modes 


\title{
Conclusions
}

Using the obtained simulation results at the stage of preparing control programs for CNC machines allows you to compare possible processing options to determine the most efficient. Modeling of processes is possible when using CAM systems using on PC with average productivity.

\section{References}

[1] Ustroystvo dlya opredeleniya zhestkosti stankov: A.s. 1426700 USSR, MKI ${ }^{4}$ B23 B25/06 /V.S. Korotkov, V.L. Zavatskiy, V.I. Nechiporenko i dr. (USSR). - 3s.

[2] Diagnosticheskoe ustroystvo dlya ispytanya frezernyh stankov s programnym upravleniyem: A.s 1328086 USSR, MKI ${ }^{4}$ B23 C9/00 / V.S. Korotkov, A.V. Yakimov, N.S. Ivchenko (USSR). - 4s.

[3] De Bor K. (1985). Prakticheskoe rukovodstvo po splaynam [Splines Practical Guide]. Moskva: Radio i svyaz [Russian language].

[4 Korneychuk N.P. (1984). Splayni v teorii priblizheniy [splines in approximation theory]. Moskva: Nauka [Russian language].

[5] Ligun A.A., Shumeyko A.A. (1997). Asimptoticheskie metody vosstanovleniya krivyh [Asymptotic Curve Recovery Methods]. Kyiv: Izd. Instituta matematiki NAN Ukrainy [Russian language].

[6] Sakai M., Usmani R. (1984). Biquadratic Spline Approximations. RIMS, Kyoto Univ., 20, 431 446.

[7] Lancaster P., Salkauskas K. (1990). Curve and Surface Fitting. An Introdution. Calgary: Acadamic Press.

[8] Zavialov J.S., Leus V.F., Skorospelov V.F. (1985). Splainy v ingenernoi geometrii [Splines in Engineering Geometry ]. Moskva: Mashinostroenie, [Russian language].

[9] Zavialov J.S., Kvasov B.I., Miroshnichenko V.L. (1985). Metody splain-funkciy [Spline Function Methods]. Moskva: Nauka, [Russian language].

[10] Pronikov A.S. (1985). Programniy metod ispytania stankov [Software test method for machine tools]. Moskva: Mashinostroenie, [Russian language].

\author{
ПОБУДОВА МОДЕЛІ ПОДАТЛИВОСТІ ТЕХНОЛОГІЧНОЇ СИСТЕМИ \\ ВЕРСТАТА 3 ЧПК \\ Шумейко А.А., Коротков В.С.
}

\section{Реферат}

При виготовленні деталей на верстатах 3 ЧПК виникають пружні деформації технологічної системи, які впливають на точність обробки. Величина похибок, що виникають при цьому, залежить від режимів обробки і технічного стану технологічної системи верстата. Визначення можливих відхилень розмірів від дії сил різання створює можливість вносити в керуючу програму обробки корекції для компенсації похибок.

Метою роботи є створення методики розрахунку очікуваних похибок руху формоутворюючого інструменту на верстатах з ЧПК при дії сил різання у всьому діапазоні робочих навантажень.

Для досягнення поставленої мети необхідно створити математичну модель процесу формоутворення при обробці на верстатах з ЧПК, яка дозволяє отримати необхідну інформацію для точного розрахунку траєкторії руху інструментів при заданих режимах обробки.

Для здійснення прогнозу точності обробки при використанні сплайнів запропонована математична модель формування розмірів деталей при обробці різанням. За результатами імітації робочих навантажень на верстаті з ЧПК і отримання даних про податливість технологічної системи проводиться моделювання обробки з визначенням величини очікуваних похибок. 
Використання отриманих результатів моделювання на етапі підготовки керуючих програм для верстатів з ЧПУ дозволяє порівнювати можливі варіанти процесу обробки і визначати більш ефективний. Моделювання процесів можливо при використанні систем автоматизованого проектування з комп'ютерами середньої продуктивності.

В умовах реального виробництва застосування розроблених методів і моделей дозволить підвищити точність обробки на верстатах з ЧПК і підвищити ефективність виробництва в цілому.

\section{Література}

1. Устройство для определения жесткости станков: А.с. 1426700 СССР, МКИ ${ }^{4}$ В23 В25/06 Заявка №4254994 30.03.1987; опубл. 30.09.1988 Бюл.№36.

2. Диагностическое устройство для испытания фрезерных станков с программным управлением: А.с. 1328086 СССР, МКИ В23 С9/00. Заявка №4038252 18.03.1986; опубл. 07.08.1987 Бюл.№29.

3. Де Бор К. Практическое руководство по сплайнам / К.Де Бор . - М: Радио и связь, 1985 .$303 \mathrm{c}$.

4. Корнейчук Н.П. Сплайны в теории приближения. - М.: Наука, 1984, 352 с.

5. Лигун А.А., Шуиейко А.А. Асимптотические методы восстановления кривых. - К.: Изд. Института математики НАН Украины, 1997. - 358 с.

6. Sakai M. Biquadratic Spline Approximations / M.Sakai, R.Usmani // RIMS, Kyoto Univ. . - 1984. - №20. - C. 431-446.

7. Lancaster P. Curve and Surface Fitting. An Introdution / P.Lancaster, K.Salkauskas. - Calgary: Acadamic Press, 1990. - 280 p.

8. Завьялов Ю.С., Леус В.А., Скороспелов В.А. Сплайны в инженерной геометрии. - М.: Машиностроение, 1985. - $224 \mathrm{c}$.

9. Завьялов Ю.С., Квасов Б.И., Мирошниченко В.Л. Методы сплайн-функций,. М.: Наука, 1980. $-350 \mathrm{c}$

10. Проников А.С. Программный метод испытания станков. М.: Машиностроение. 1985. - 288 с. 